\title{
Kemampuan Pemecahan Masalah Open-Ended Siswa SMP Berdasarkan Tahapan Polya
}

\section{Junior High School Student Problem Solving Ability Based on Polya Stages}

\section{Ni Putu Gita Arilaksmi ${ }^{*}$, Susiswo', I Made Sulandra ${ }^{1}$}

1Universitas Negeri Malang

*Email Korespondensi: gitaarilaksmi.26@gmail.com

\begin{tabular}{lll}
\hline \hline Info Artikel & \\
\hline Diterima & $:$ & 31 Jan 21 \\
Direvisi & $:$ & 11 Feb 21 \\
Diterbitkan & $:$ & 28 Feb 21
\end{tabular}

Kata Kunci:

Pemecahan Masalah, Open-

Ended, Polya

Cara merujuk artikel ini:

Arilaksmi, Ni Putu G., Susiswo, S., \& Sulandra, I Made. (2021). Kemampuan Pemecahan Masalah OpenEnded Siswa SMP Berdasarkan Tahapan Polya. Vygotsky: Jurnal Pendidikan Matematika dan Matematika, 3

(1), 1-12. Diunduh dari https://jurnalpendidikan. unisla.ac.id/index.php/ VoJ/article/view/346

\begin{abstract}
Describing students' open-ended problem-solving abilities based on Polya's stages is the aim of this study. This study uses a descriptive approach to qualitative methods. The research was conducted at SMPN 21 Malang in class VIII.6 by filtering students into three representing high, medium, and low math abilities. The researcher himself, an open-ended problem test, and an interview guide were the instruments used. Students with high mathematical abilities have excellent abilities in solving problems and fulfilling the four stages of Polya. Students with mathematical abilities fulfill the three stages of Polya without checking again and can categorize as useful. Students with low math abilities do not meet the four stages of Polya's problem solving and are categorized as unfavorable.
\end{abstract}

Abstrak
Mendeskripsikan kemampuan pemecahan masalah
open-ended siswa berdasarkan tahapan Polya ialah
tujuan penelitian ini. Penelitian ini menggunakan
pendekatan deksriptif pada metode kualitatif.
Penelitian dilaksanakan di SMPN 21 Malang pada
kelas VIII.6, dengan menyaring siswa menjadi tiga
yang mewakili kemampuan matematika tinggi,
sedang, dan rendah. Peneliti sendiri, tes masalah
open-ended, dan pedoman wawancara ialah
instrument yang digunakan. Siswa berkemampuan
matematika tinggi mempunyai kemampuan sangat
baik dalam memecahkan masalah dan memenuhi
keempat tahapan Polya. Siswa berkemampuan
matematika sedang memenuhi tiga tahapan Polya
tanpa mengecek kembali dan dapat dikategorikan
baik. Siswa berkemampuan matematika rendah
tidak memenuhi keempat tahapan pemecahan
masalah Polya dan dikategorikan kurang baik.

Copyright (C) 2021 Vygotsky: Jurnal Pendidikan Matematika dan Matematika. All right reserved 


\section{PENDAHULUAN}

Pemecahan masalah merupakan suatu keterampilan seseorang dalam menyusun strategi dalam memecahkan masalah yang diberikan (Özsoy, Kuruver, \& Çakiroglu, 2015). Salah satu bagian penting dalam kurikulum matematika yakni melakukan pembelajaran dengan pendekatan pemecahan masalah. Melalui proses belajar dan pemecahan, siswa akan memperoleh pengalaman dalam menggunakan pengetahuan dan keterampilannya sendiri untuk diterapkan dalam pemecahan masalah non rutin (Azinar, dkk., 2020). Pemecahan masalah juga dapat dikatakan sebagai suatu aksi intelektual agar mendapatkan penyelesaian dari permasalahan yang mengaitkan pemahaman dan kemahiran yang dimiliki sebelumnya (Maimunah, dkk., 2016). Hal itu selaras dengan Ulya (2016) yang mengungkapkan bahwa pemecahan masalah ialah kemampuan untuk mengeksplorasi pengetahuan sebelumnya dalam menghadapi situasi baru. Berlatarkan penjabaran di atas, pemecahan masalah ialah suatu aktivitas yang melibatkan pengetahuan serta pengalaman untuk menyusun strategi untuk memecahkan masalah.

Salah satu kemampuan yang patut dikuasai oleh siswa adalah pemecahan masalah (Aziza, 2019). Mampu mengorganisasikan gaya berpikir dengan baik adalah salah satu tuntutan dalam kemampuan pemecahan masalah matematika (English \& Sriraman, 2010). Hal itu serupa dengan Nengsih, Susiswo, \& Sa'dijah (2019), mengutarakan jika dengan adanya kemampuan pemecahan masalah maka mampua mendorong siswa untuk berpikir secara sistematis, logis, kritis, dan pantang menyerah untuk menciptakan penyelesaian masalah yang tengah dihadapi. Terdapat empat tahapan dari pemecahan masalah (problem solving) menurut Polya (2004); siswa harus mampu memahami masalah, lalu merencanakan strategi, setelah itu melaksanakan rencana, terakhir mengecek kembali penyelesaian yang telah dilaksanakan. Kemampuan pemecahan masalah siswa salah satunya dapat ditingkatkan dengan upaya memberikan latihan yang bersifat open-ended. Kemampuan pemecahan masalah diharapkan mampu untuk mengembangkan, melatih, dan meningkatkan kemampuan siswa Indonesia guna menyongsong perkembangan pendidikan dunia.

Masalah open-ended memungkinkan siswa untuk melatih, menumbuhkan, dan meningkatkan kemampuan pemecahan masalah (Suwandi, Hasnunidah, \& Marpaung, 2016). Menurut Bishara (2016), penyajian masalah secara open-ended berguna untuk menciptakan situasi berpikir orisinal karena berisi pertanyaan terbuka yang memungkinkan siswa untuk menemukan lebih dari satu kemungkinan jawaban. Masalah open-ended dibagi dalam tiga jenis yakni masalah yang menyajikan satu jawaban benar dengan cara yang banyak, menyajikan satu cara dengan banyak jawaban, atau mengandung banyak cara untuk memperoleh banyak jawaban benar (Hidayat \& Sariningsih, 2018; Rajiman, 2018). Banyaknya strategi dalam memecahkan masalah dapat menciptakan pembelajaran yang efektif, karena pemberian masalah dapat mendorong 
siswa untuk terampil dalam memecahkan masalah (Nataraj \& Manjula, 2012; Pathak, 2013). Hal itu juga didukung oleh Hastuti, dkk (2014) yang menjelaskan bahwa pemberian masalah open-ended dapat membuat tujuan pembelajaran tercapai secara maksimal.

Berdasarkan hasil penelitian Amalina \& Ekawati (2020) menjelaskan bahwa siswa dengan kemampuan matematika tinggi dapat melaksanakan semua tahap pemecahan masalah Polya. Siswa bekemampuan matematika sedang dapat melaksanakan tiga tahapan Polya namun tidak memenuhi tahap mengecek kembali yaitu menggunakan cara lain untuk menyelesaikan masalah dan membuat kesimpulan. Siswa berkemampuan matematika rendah tidak menunjukkan kecukupan data pada tahap memahami masalah serta tidak dapat melaksanakan tahapan selanjutnya dalam memecahkan masalah yang disajikan. Hasil penelitian yang dilakukan Simatupang, dkk (2019) menunjukkan bahwa siswa yang memiliki kemampuan matematika tinggi mampu menunjukkan keempat tahapan Polya, siswa berkemampuan sedang hanya tidak mampu menunjukkan tahap mengecek kembali, dan siswa yang berkemampuan rendah hanya mampu menunjukkan tahap memahami masalah.

Berdasarkan hasil dari beberapa penelitian sebelumnya, pada penelitian ini peneliti akan berfokus meneliti kemampuan pemecahan masalah open-ended bangun datar. Mencari luas dari bangun datar melibatkan beberapa proses. Proses itu berkaitan dengan bagaimana cara membagi kemudian memilah bangun menjadi beberapa bangun datar lain (Muhsetyo, 2016). Masalah open-ended pada penelitian ini adalah masalah yang dapat menyajikan satu jawaban benar dengan cara yang banyak. Hal itu dilakukan untuk dapat melihat lebih dalam bagaimana siswa dalam merencanakan dan melaksanakan strategi serta melihat apakah hasil akhir yang disajikan sama atau berbeda. Penelitian ini bertujuan untuk dapat mendeskripsikan kemampuan pemecahan masalah open-ended siswa SMP berdasarkan tahapan Polya.

\section{METODE PENELITIAN}

Metode kualitatif dengan pendekatan deskriptif serta sampel dipilih dengan cara purposive sampling. Subjek dalam penelitian ialah tiga siswa pada kelas VIII.6 di SMPN 21 Malang berkemampuan matematika yang tinggi, sedang, dan rendah. Subjek dipilih berdasarkan rekomendasi guru, prestasi belajar siswa, dan mampu menyelesaikan seluruh tes dengan membuat sedikitnya dua strategi penyelesaian. Instrumen penelitian yang dipakai ialah peneliti sendiri, lembar tes, dan pedoman wawancara.

Siswa diberikan dua masalah open-ended. Dua masalah tersebut berkaitan dengan mencari luas bangun datar tak beraturan sedikitnya dengan dua cara berbeda. Tingkat kesulitan dari tiap soal didasari atas kerumitan bangun, ukuran bangun yang disajikan, ketelitian dalam memahami masalah, merencanakan strategi, melaksanakan strategi, serta ketepatan dalam menghitung dan mengecek kembali. Selama proses mengerjakan tes, siswa diamati untuk mendapatkan informasi yang 
mendukung hasil penelitian. Gambar 1 menyajikan cuplikan masalah penelitian. Disajikan juga Tabel 1 yang menjabarkan deskripsi tahapan kemampuan pemecahan masalah. Tabel 2 menyajikan kategori kemampuan pemecahan masalah. Kategori kemampuan pemecahan masalah open-ended siswa didasari pada pemilihan subjek penelitian yang sudah dijelaskan sebelumnya.

Perhatikan gambar dibawah ini dengan seksama! Tentukan luas dari bangun yang dibatasi garis berwarna jingga. Kerjakan minimal dengan dua strategi (cara) penyelesaian yang berbeda! (Catatan: jarak antar titik bernilai satu sentimeter).
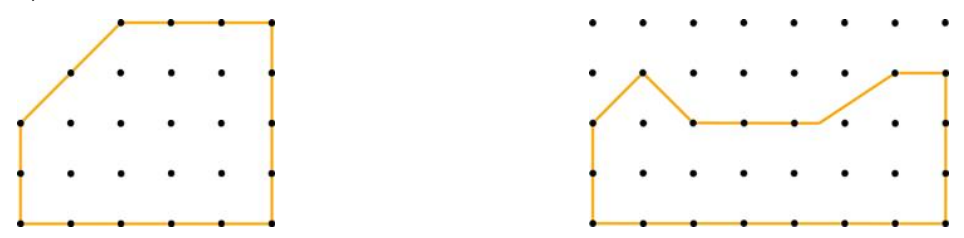

Gambar 1. Cuplikan Masalah

Tabel 1. Deskripsi Tahapan Kemampuan Pemecahan Masalah

\begin{tabular}{|c|c|}
\hline Tahapan & Deskripsi \\
\hline $\begin{array}{l}\text { Siswa mampu } \\
\text { memahami } \\
\text { masalah }(\mathrm{MM})\end{array}$ & $\begin{array}{l}\text { Secara eksplisit telah mampu memahami permasalahan yang } \\
\text { disajikan dengan cara menuliskan informasi-informasi pada } \\
\text { masalah yang disajikan. Siswa juga dapat mencari panjang sisi } \\
\text { yang belum diketahui. }\end{array}$ \\
\hline $\begin{array}{l}\text { Siswa mampu } \\
\text { merencanakan } \\
\text { strategi (MS) }\end{array}$ & $\begin{array}{l}\text { Melakukan pembagian bangun-bangun datar pada pola } \\
\text { gambar yang disediakan, minimal dengan dua strategi yang } \\
\text { berbeda. Memanipulasi gambar menjadi beberapa bangun } \\
\text { datar }\end{array}$ \\
\hline $\begin{array}{l}\text { Siswa mampu } \\
\text { melaksanakan } \\
\text { strategi (MR) }\end{array}$ & $\begin{array}{l}\text { Melaksanakan strategi pemecahan masalah sesuai rencana } \\
\text { penyelesaian yang telah dibuat. Memperoleh luas bangun } \\
\text { datar yang ditanyakan. }\end{array}$ \\
\hline $\begin{array}{l}\text { Siswa mampu } \\
\text { mengecek } \\
\text { kembali }(\mathrm{MK})\end{array}$ & $\begin{array}{l}\text { Siswa menghasilkan jawaban yang tepat dan tidak melakukan } \\
\text { kesalahan menghitung pada seluruh strategi penyelesain yang } \\
\text { dibuat olehnya. }\end{array}$ \\
\hline
\end{tabular}

Tabel 2. Kategori Kemampuan Pemecahan Masalah Open-Ended

\begin{tabular}{|c|c|}
\hline Kategori & Deskripsi \\
\hline Sangat Baik & $\begin{array}{l}\text { Membuat sedikitnya dua strategi yang berbeda. Mampu } \\
\text { memecahkan masalah dengan menerapkan empat tahapan Polya. }\end{array}$ \\
\hline Baik & $\begin{array}{l}\text { Membuat sedikitnya dua strategi yang berbeda. Mampu } \\
\text { memecahkan masalah dengan menerapkan tiga tahapan Polya (tidak } \\
\text { memenuhi tahapan mengecek kembali). }\end{array}$ \\
\hline Cukup Baik & $\begin{array}{l}\text { Membuat sedikitnya dua strategi yang berbeda. Mampu } \\
\text { memecahkan masalah dengan menerapkan dua tahapan Polya (tidak } \\
\text { memenuhi tahapan melaksanakan strategi dan mengecek kembali). }\end{array}$ \\
\hline Kurang Baik & $\begin{array}{l}\text { Membuat sedikitnya dua strategi yang berbeda. Tidak memenuhi } \\
\text { seluruh tahapan pemecahan masalah. }\end{array}$ \\
\hline
\end{tabular}


Data dikumpulkan dengan menggunakan teknik secara langsung oleh peneliti melalui tes dan wawancara secara semi terstruktur. Reduksi data digunakan untuk menganalisis data kemudian menyajikan data penelitian. Triangulasi data dilakukan dengan hasil wawancara. Terakhir, adalah tahapan menyimpulkan.

\section{HASIL PENELITIAN DAN PEMBAHASAN}

Mewakili tiga jenis tingkatan yakni tinggi (V1), sedang (V2), dan rendah (V3). Empat tahapan Polya digunakan dalam melihat kemampuan pemecahan masalah siswa. Pertama memahami masalah yang disuguhkan, kedua merencanakan strategi penyelesaian, ketiga melaksanakan strategi penyelesaian, dan keempat mengecek kembali.

\section{Hasil Pekerjaan Siswa Berkemampuan Matematika Tinggi (V1)}

Hasil pekerjaan nomor 1 subjek V1 terlihat pada Gambar 2.

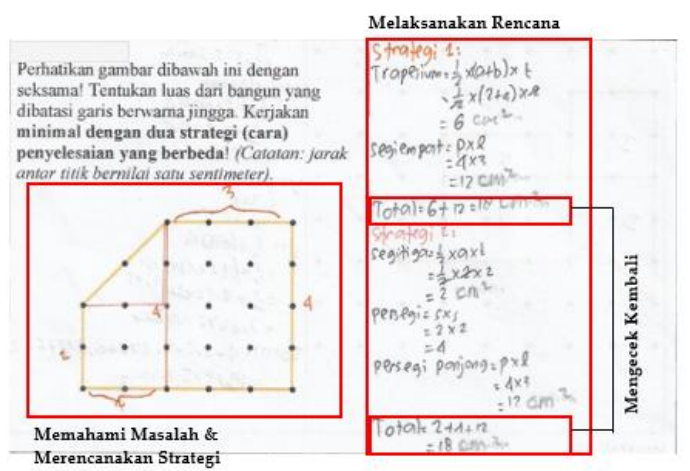

Gambar 2. Pekerjaan Nomor 1 Subjek V1

Berdasarkan hasil pekerjaan nomor 1, subjek V1 secara eksplisit telah memahami permasalahan yang disajikan. Subjek V1 juga telah mampu mencari panjang sisi yang belum diketahui dan menuliskan informasi tersebut. Pada tahap merencanakan strategi, subjek V1 sudah mampu melakukan pembagian bangun-bangun datar pada pola gambar yang disediakan dengan dua strategi yang berbeda. Strategi pertama, subjek V1 membagi bangun menjadi dua yakni trapesium dan persegi panjang. Strategi kedua dengan cara membagi bangun menjadi tiga bagian yakni segitiga, persegi, dan persegi panjang. Tahapan melaksanakan strategi juga sudah dapat dilaksanakan oleh subjek V1, mampu mengimplementasikan strategi yang dibuat dengan tepat yakni menjumlahkan luas dari setiap bangun yang dibagi olehnya. Ketepatan itu juga dapat dilihat dari segi penggunaan rumus, perhitungan, maupun menempatkan satuan. Hanya terdapat sedikit kekeliruan pada strategi 1, subjek V1 menuliskan keterangan segiempat tetapi rumus yang digunakan adalah rumus persegi panjang. Hal ini dikonfirmasi oleh peneliti saat wawancara. Berikut cuplikan wawancara subjek V1 dengan peneliti 
P: Coba lihat hasil pekerjaan nomor 1 kamu, apakah kamu sudah yakin tepat semuanya?

V Ada sedikit typo $\mathrm{Bu}$, seharusnya ini saya menulis persegi

1: panjang tapi yang saya tulis malah segiempat.

Subjek V1 telah menyadari kekeliruannya. Tahapan proses mengecek kembali juga dapat dilalui oleh subjek V1 sebab dalam hasil pekerjaan nomor 1 hasil akhir dari strategi 1 maupun 2 menghasilkan jawaban yang tepat. Selanjutnya, hasil pekerjaan nomor 2 subjek V1 disajikan pada Gambar 3.

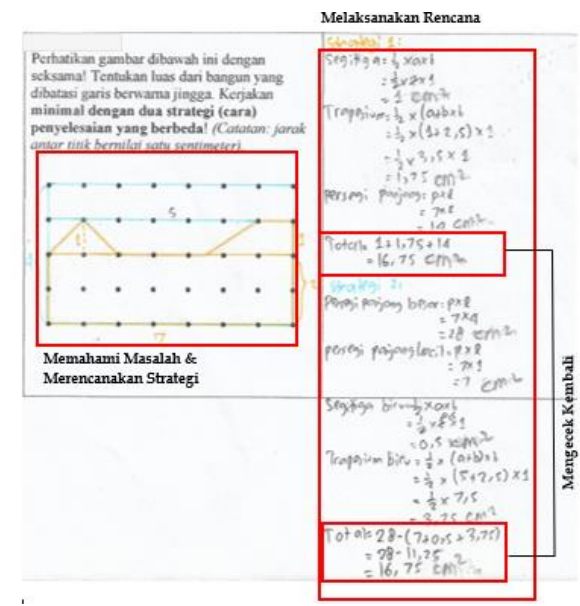

Gambar 3. Pekerjaan Nomor 2 Subjek V1

Serupa dengan hasil pekerjaan nomor 1, pada hasil pekerjaan nomor 2 subjek V1 secara eksplisit telah memahami permasalahan yang disajikan. Subjek V1 juga telah mampu mencari panjang sisi yang belum diketahui dan menuliskan informasi tersebut. Pada tahap merencanakan strategi, subjek V1 sudah mampu melakukan pembagian bangun-bangun datar pada pola gambar yang disediakan dengan dua strategi yang berbeda. Pembagian bangun juga melingkupi daerah luar sehingga tidak hanya berfokus di dalam tetapi juga dapat melihat strategi berbeda. Strategi pertama, subjek V1 membagi bangun menjadi tiga yakni trapesium, segitiga, dan persegi panjang. Strategi kedua dengan cara membagi bangun menjadi empat bagian yakni persegi panjang besar (menarik garis titik-titik terluar sehingga membentuk persegi panjang besar), persegi panjang kecil (bagian dalam), segitiga (bagian luar), dan trapesium (bagian luar). Proses selanjutnya adalah melakukan perhitungan. Pada penyelesaian masalah kedua subjek V1 melakukan operasi penguarangan daerah keseluruhan dengan komponen kecil-kecil lainnya sehingga menghasilkan jawaban yang sama seperti jawaban pada strategi 1 . Penjelasan tadi menunjukkan bahwa subjek V1 telah mampu melaksanakan strategi dan mengecek kembali.

\section{Hasil Pekerjaan Siswa Berkemampuan Matematika Sedang (V2)}

Gambar 4 di bawah ini menyajikan hasil pekerjaan nomor 1 subjek V2. 


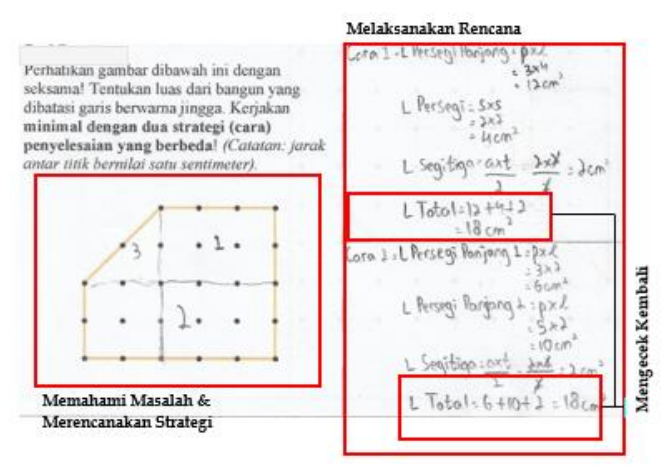

Gambar 4. Pekerjaan Nomor 1 Subjek V2

Bersumber Gambar 4, subjek V2 secara eksplisit telah memahami permasalahan yang disajikan. Subjek V2 tidak menuliskan informasi terkait panjang sisi yang belum diketahui. Hal ini dikonfirmasi oleh peneliti saat wawancara. Berikut cuplikan wawancara subjek V2 dengan peneliti.

P: Jelaskan apa yang dapat kamu pahami pada masalah yang disajikan?

V2: Diminta mencari luas dengan dua cara berbeda. Jarak antar titik bernilai $1 \mathrm{~cm} \mathrm{Bu}$.

P: Bagaimana cara kamu untuk mengetahui ukuran tiap sisinya?

V2: Saya hitung jarak antar titiknya Bu satu-satu.

P: Tidak ditulis keterangannya ya?

V2: Langsung di jawabannya Bu.

Berdasarkan cuplikan wawancara di atas, subjek V2 langsung menuliskan ukuran tiap sisinya pada tahap merencanakan strategi. Tahapan merencanakan strategi telah dilakukan oleh subjek V2. Siswa juga mampu memanipulasi gambar menjadi beberapa bangun datar. Strategi pertama dan kedua dilakukan dengan membagi bangun menjadi tiga bagian. Pertama dengan membagi menjadi persegi panjang, persegi, dan segitiga. Kedua dengan membagi menjadi 2 persegi panjang dan segitiga. Proses melaksanakan strategi adalah dengan mencari luas tiap bagian kemudian menjumlahkannya. Mengecek kembali juga sudah dilewati oleh subjek V2 sebab berdasarkan strategi pertama dan kedua telah menghasilkan jawaban yang sama dan tepat. Selanjutnya di bawah ini juga disajikan Gambar 5 terkait hasil pekerjaan nomor 2 subjek V2. 


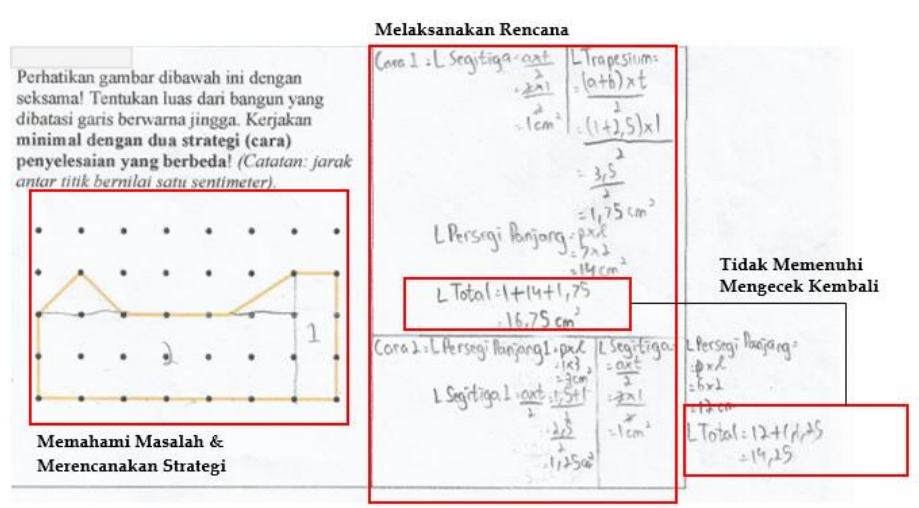

Gambar 5. Pekerjaan Nomor 2 Subjek V2

Melihat Gambar 5, subjek V2 dapat diketahui bahwa secara eksplisit juga telah memahami permasalahan yang disajikan. Subjek V2 langsung menuliskan informasi pada lembar jawaban seperti yang dilakukan olehnya pada penyelesaian nomor 1 . Tahapan merencanakan strategi dilakukan dengan memanipulasi gambar menjadi beberapa bangun datar. Strategi pertama yakni membagi bangun menjadi tiga bagian terdiri atas segitiga, persegi panjang, dan trapesium. Strategi kedua dilakukan dengan membagi bangun menjadi empat bagian yakni membuat 2 persgei panjang dan 2 segitiga. Dalam melaksanakan strategi proses perhitungan pada strategi pertama sudah tepat sebab menghasilkan jawaban yang benar. Hal ini berkebalikan dengan strategi kedua, hasil perhitungan berbeda dengan strategi pertama. Setelah diteliti subjek V2 mengalami kesalahan perhitungan pada tahapan mencari luas segitiga 1. Subjek V2 seharunya mengalikan alas dengan tinggi namun dalam penerapannya melakukan penjumlahan. Bersumber dari uraian di atas, subjek V2 tidak memenuhi tahapan mengecek kembali sebab hasil akhir strategi pertama dan kedua berbeda.

\section{Hasil Pekerjaan Siswa Berkemampuan Matematika Rendah (V3)}

Gambar 6 menyajikan hasil pekerjaan nomor 1 yang dilakukan oleh subjek V3.

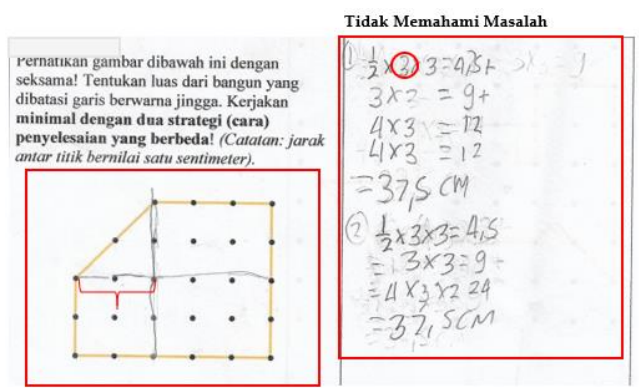

Gambar 6. Pekerjaan Nomor 1 Subjek V3

Subjek V3 belum memahami masalah yang disajikan, sebab subjek V3 kurang tepat dalam mengintepretasikan informasi yang diberikan. Jarak antar titik bernilai $1 \mathrm{~cm}$, tetapi subjek V3 menganggap bahwa yang dihitung adalah jumlah titiknya. Hal ini telah dikonfirmasi 
peneliti pada cuplikan wawancara terlampir.

P: Jelaskan kepada saya apa yang dapat kamu pahami pada masalah yang disajikan?

V3: Diminta mencari luas dengan dua cara berbeda.

P: Coba jelaskan mengapa alas segitiga berukuran $3 \mathrm{~cm}$ ?

V3: Titiknya ada tiga Bu.

Bersumber dari cuplikan wawancara di atas beserta hasil pekerjaan subjek V3 pada nomor 1, subjek V3 belum sepenuhnya memahami masalah yang disajikan. Hal ini membuat jawaban yang dihasilkan tidak tepat. Melihat dari rencana yang dibuat strategi pertama dan kedua tidak jauh berbeda hanya sistematika penulisannya yang dibedakan. Pada tahap melaksanakan strategi dan mengecek kembali tidak terpenuhi. Subjek V3 tidak memenuhi seluruh tahapan Polya. Setelah melihat hasil pekerjaan subjek V3 pada nomor 1, Gambar 7 menyajikan hasil pekerjaan nomor 2.

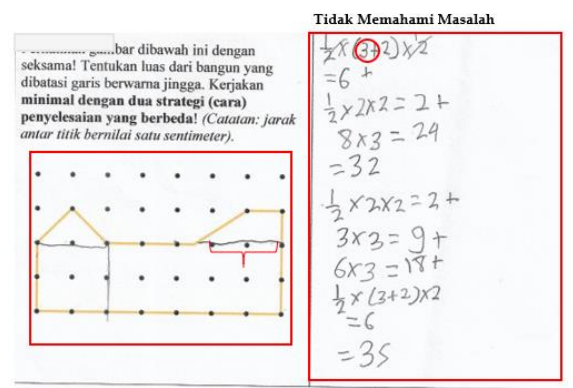

Gambar 7. Pekerjaan Nomor 2 Subjek V3

Menelisik Gambar 7, tidak jauh berbeda dengan hasil pekerjaan nomor 2. Subjek V3 belum memahami masalah yang disajikan. Tidak memahami masalah membuat tahapan selanjutnya tidak tercapai secara maksimal. Subjek V3 tidak memenuhi seluruh tahapan Polya untuk memecahkan masalah nomor 2 .

\section{Pembahasan}

Rangkuman hasil pekerjaan subjek V1, V2, dan V3 dalam memecahkan masalah nomor 1 dan 2 dilihat pada Tabel 3 .

Tabel 3. Rangkuman Pekerjaan Subjek V1, V2, dan V3

\begin{tabular}{lcccccccccccc}
\hline No. & \multicolumn{4}{c}{ Subjek V1 } & \multicolumn{4}{c}{ Subjek V2 } & \multicolumn{4}{c}{ Subjek V3 } \\
\cline { 2 - 14 } Tes & MM & MS & MR & MK & MM & MS & MR & MK & MM & MS & MR & MK \\
\hline 1. & $*$ & $*$ & $*$ & $*$ & $*$ & $*$ & $*$ & $*$ & - & - & - & - \\
2. & $*$ & $*$ & $*$ & $*$ & $*$ & $*$ & $*$ & - & - & - & - & - \\
\hline
\end{tabular}

Merujuk pada Tabel 3 didapatkan bahwa subjek V1 memiliki kategori kemampuan pemecahan masalah sangat baik. Subjek V1 mampu membuat sedikitnya dua strategi yang berbeda serta mampu memecahkan masalah dengan menerapkan keempat tahapan Polya. 
Subjek V2 dapat dikategorikan memiliki kemampuan pemecahan masalah baik, mampu membuat sedikitkanya dua strategi yang berbeda. Subjek V2 mampu memecahkan masalah dengan menerapkan tiga tahapan Polya yakni memahami masalah, merencanakan strategi, melaksanakan strategi tetapi tidak memenuhi tahapan mengecek kembali. Hasil pekerjaan subjek V3 memperlihatkan bahwa kemampuan pemecahan masalah siswa berada pada kategori kurang baik. Subjek V3 mampu membuat sedikitnya dua strategi yang berbeda, tetapi tidak memenuhi seluruh tahapan pemecahan masalah Polya karena belum sepenuhnya memahami masalah yang disajikan. Hal ini mengakibatkan jawaban yang dihasilkan tidak tepat. Meninjau dari rencana yang dibuat strategi pertama dan kedua tidak jauh berbeda hanya sistematika penulisannya yang dibedakan. Hal itu berimbas kepada tahapan melaksanakan strategi dan mengecek kembali yang juga tidak terpenuhi.

Melalui pemahaman dan kemahiran yang dimiliki, siswa dapat memecahkan masalah yang diberikan (Febriyanti \& Novitasari, 2019). Merujuk pada hasil, kemampuan memecahkan masalah siswa dapat ditinjau serta ditingkatkan dengan cara memberikan masalah openended secara rutin. Selaras dengan hasil penelitian Thursina \& Sutriyono (2018), pemberian masalah open-ended secara rutin dipercaya bisa meningkatkan kemampuan siswa untuk memecahkan masalah matematika jauh lebih baik. Selanjutnya Hidayat \& Sariningsih (2018) juga mengatakan bahwa masalah open-ended dapat melatih dan mengembangkan kemampuan siswa dalam memecahkan masalah. Menurut Aini (2016) dengan menggunakan pendekatan secara open-ended dapat menjadi alternatif pembelajaran matematika siswa di sekolah. Alternatif lainnya dengan memperhatikan proses penyampaian materi saat pembelajaran di kelas (Fitrianingrum \& Basir, 2020). Bersumber dari hasil penelitian ini, kemampuan pemecahan masalah yang masih berkembang atau kurang baik dapat ditingkatkan dengan memberikan masalah open-ended secara berkala atau rutin.

\section{SIMPULAN DAN SARAN}

Bersumber dari hasil penelitian yang telah dilakukan, kemampuan pemecahan masalah open-ended siswa berkemampuan matematika tinggi dapat dikategorikan sangat baik. Mampu menyajikan sedikitnya dua strategi yang berbeda dan melaksanakan keempat tahapan Polya. Selanjutnya subjek berkemampuan matematika sedang memiliki kategori kemampuan pemecahan masalah baik. Dikatakan baik sebab mampu menyajikan sedikitnya dua strategi yang berbeda dan melaksanakan tiga tahapan Polya tanpa mengecek kembali. Subjek kemampuan matematika rendah belum mampu melaksanakan keempat tahapan Polya sehingga dapat dikategorikan memiliki kemampuan pemecahan masalah yang 
kurang baik. Harapannya hasil dari penelitian ini dapat dijadikan masukkan oleh guru dalam melaksanakan kegiatan belajar mengajar di kelas. Menaruh perhatian lebih terhadap siswa kurang dalam memecahkan suatu masalah juga dapat dilakukan oleh guru. Penggunaan masalah open-ended bisa diberikan secara rutin guna meningkatkan kemampuan siswa dalam memecahkan masalah.

\section{DAFTAR RUJUKAN}

Aini, I. N. (2016). Upaya Meningkatkan Kemampuan Pemecahan Masalah Matematik Siswa Melalui Pendekatan Open-Ended. JES-MAT (Jurnal Edukasi Dan Sains Matematika), 2(2). https://doi.org/10.25134/jesmat.v2i2.345

Amalina, S. V., \& Ekawati, R. (2020). Profile of Open-Ended Problem Solving Based on Polya's Steps Viewed from Mathematical Ability Level of Junior High School Students. MATHEdunesa, 9(2), 402-411. https:// doi.org/10.26740/mathedunesa.v9n2.p402-411

Azinar, J. A., Munzir, S., \& Bahrun. (2020). Students' logical-mathematical intelligence through the problem-solving approach. Journal of Physics: Conference Series, 1460, 012024. https://doi.org/10.1088/1742$6596 / 1460 / 1 / 012024$

Aziza, M. (2019). Kemampuan pemecahan masalah siswa dalam menyelesaikan soal tertutup dan terbuka pada pokok bahasan lingkaran. Pythagoras: Jurnal Pendidikan Matematika, 14(2), 126-138. https:// doi.org/10.21831/pg.v14i2.26563

Bishara, S. (2016). Creativity in unique problem-solving in mathematics and its influence on motivation for learning. Cogent Education, 3(1). https:/ / doi.org/10.1080/2331186X.2016.1202604

English, L., \& Sriraman, B. (2010). Problem Solving for the 21st Century. In B. Sriraman \& L. English (Eds.), Theories of Mathematics Education (pp. 263-290). Springer Berlin Heidelberg. https:/ / doi.org/10.1007/978-3642-00742-2_27

Febriyanti, R., \& Novitasari, N. (2019). Pola Pemecahan Masalah Matematika Pada Siswa yang Berkemampuan Setara. VYGOTSKY, 1(2), 56. https:/ / doi.org/10.30736/vj.v1i2.126

Fitrianingrum, F., \& Basir, M. A. (2020). Analisis Kemampuan Representasi Matematis Siswa dalam Menyelesaikan Soal Aljabar. VYGOTSKY, 2(1), 1. https:// doi.org/10.30736/vj.v2i1.177

Hastuti, J., Sugiatno, S., \& Nursangaji, A. (2014). Pengembangan Soalopen Ended Problem Solving Materi Segi Empat untuk Siswa Kelas VII SMP. Jurnal Pendidikan dan Pembelajaran UntanDoctoral dissertation, Tanjungpura University, 3(12).

Hidayat, W., \& Sariningsih, R. (2018). Kemampuan Pemecahan Masalah Matematis dan Adversity Quotient Siswa SMP Melalui Pembelajaran Open Ended. JNPM (Jurnal Nasional Pendidikan Matematika), 2(1), 109118.

Maimunah, M., Purwanto, P., Sa'dijah, C., \& Sisworo, S. (2016). Penerapan Model Pembelajaran Matematika Melalui Pemecahan Masalah untuk 
Meningkatkan Penalaran Matematis Siswa Kelas X-A SMA AlMuslimun. Jurnal Review Pembelajaran Matematika, 1(1), 17-30. https:// doi.org/10.15642/jrpm.2016.1.1.17-30

Muhsetyo, G. (2016). Mengembangkan Masalah Sederhana Mencari Luas Bangun Datar Menjadi Masalah Open-Ended Konseptual. JPM (Jurnal Pembelajaran Matematika), 3(1).

Nataraj, P. N., \& Manjula, M. (2012). A study of problem solving ability among the matriculation school students. International Journal of Teacher Education Research (IJTER), 1(4), 38-40.

Nengsih, L. W., Susiswo, \& Sa'dijah, C. (2019). Kemampuan Pemecahan Masalah Matematika Siswa Sekolah Dasar dengan Gaya Kognitif Field Dependent. Jurnal Pendidikan: Teori, Penelitian, Dan Pengembangan, 4(2), 143-148.

Özsoy, G., Kuruver, H. G., \& Çakiroglu, A. (2015). Evaluation of Students' Mathematical Problem Solving Skills in Relation to Their Reading Levels. International Electronic Journal of Elementary Education, 8(1), 113-132.

Pathak, N. (2013). A Study of Problem Solving Ability among Undergraduate Mathematical Gifted Students. International Journal of Teacher Educational Research (IJTER), 1(4), 506-508.

Polya, G. (2004). How to solve it: A new aspect of mathematical method. Princeton University Press.

Rajiman, W. (2018). Karakteristik Pemecahan Masalah Matematika Open Ended Ditinjau dari Kemampuan Logika Siswa Kelas XI SMA Negeri 3 Wajo. Disertasi: Pascasarjana Universitas Negeri Makassar.

Simatupang, R., Elvis Napitupulu, E., \& Syahputra, E. (2019). Analysis of Mathematical Problem-Solving Abilities Taught Using Problem-Based Learning. American Journal of Educational Research, 7(11), 794-799. https://doi.org/10.12691/education-7-11-6

Suwandi, T., Hasnunidah, N., \& Marpaung, R. R. T. (2016). Pengaruh pembelajaran berbasis Masalah Open-Ended terhadap Peningkatan Kemampuan Pemecahan Masalah oleh Siswa. Jurnal Pendidikan Progresif, 6(2), 163-173.

Thursina, A. F., \& Sutriyono, S. (2018). Profil Kemampuan Pemecahan Masalah Open-Ended pada Materi Bangun Datar Segiempat bagi Siswa SMP. Pendekar: Jurnal Pendidikan Berkarakter, 1(1), 96. https:// doi.org/10.31764/pendekar.v1i1.297

Ulya, H. (2016). Profil Kemampuan Pemecahan Masalah Siswa Bermotivasi Belajar Tinggi Berdasarkan Ideal Problem Solving. Jurnal Konseling Gusijigang, 2(1). https:// doi.org/10.24176/jkg.v2i1.561 